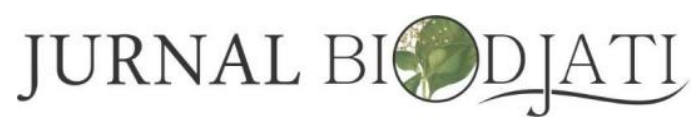

http://journal.uinsgd.ac.id/index.php/biodjati

\title{
PENGARUH EKSTRAK ETANOL DAUN SAMBILOTO TERHADAP JUMLAH DAN MOTILITAS SPERMATOZOA MENCIT JANTAN
}

\author{
Susilo $^{1}$, Budhi Akbar ${ }^{2}$, Ika Pratinaningsih ${ }^{3}$ \\ Pendidikan Biologi, Universitas Muhammadiyah Prof. Dr. Hamka, \\ Jl. Tanah Merdeka, Kp. Rambutan, Ciracas, Jakarta Timur, 13830. \\ e-mail: *2l susilo@uhamka.ac.id, ${ }^{2}$ budhiakbar@uhamka.ac.id, ${ }^{3}$ ikapratinaningsih@yahoo.com
}

\begin{tabular}{l} 
Diterima :05 November \\
2018 \\
Disetujui : 19 November \\
2018 \\
\hline e-ISSN : 2541-4208 \\
p-ISSN : 2548-1606 \\
\hline
\end{tabular}

DOI: 10.15575/biodjati.v3i2.3505
Abstrak. Tanaman sambiloto (Andrographis paniculata Ness.) merupakan salah satu tanaman obat yang dipercaya dapat mengobati berbagai penyakit seperti influenza, anti kanker, meningkatkan ketahanan tubuh dan anti-fertilitas. Penelitian ini bertujuan untuk mengetahui pengaruh dari daun sambiloto terhadap jumlah dan motilitas spermatozoa mencit (Mus musculus L.) jantan galur DDY (Deutschland, Denken, and Yoken). Sebanyak 24 ekor mencit jantan dengan berat antara 100-125gramdibagi menjadi empat kelompok perlakuan yaitu P0, P1, P2 dan P3 dengan masing-masing dosis 0, 84, 140 dan $196 \mathrm{mg} / \mathrm{kg}$ berat badan yang diberikan ekstrak etanol secara oral selama 15 hari. Hasil penelitian menunjukkan bahwa kelompok perlakuan P3 (196 mg/kg berat badan) menunjukkan jumlah spermatozoa terbanyak yaitu 7,33 juta/ml, mengalami penurunan sebesar 78,86\% terhadap kontrol. Kandungan senyawa andrografolid dan flavonoid pada ekstrak sambiloto diduga kuat menjadi penyebab penurunan jumlah dan motilitas spermatozoa mencit. Hasil penelitian ini memberikan informasi bahwa pemberian ekstrak etanol daun sambiloto berpengaruh terhadap jumlah dan motilitas spermatozoa mencit jantan.

Kata Kunci: daun sambiloto, mencit jantan, motilitas, sperma,

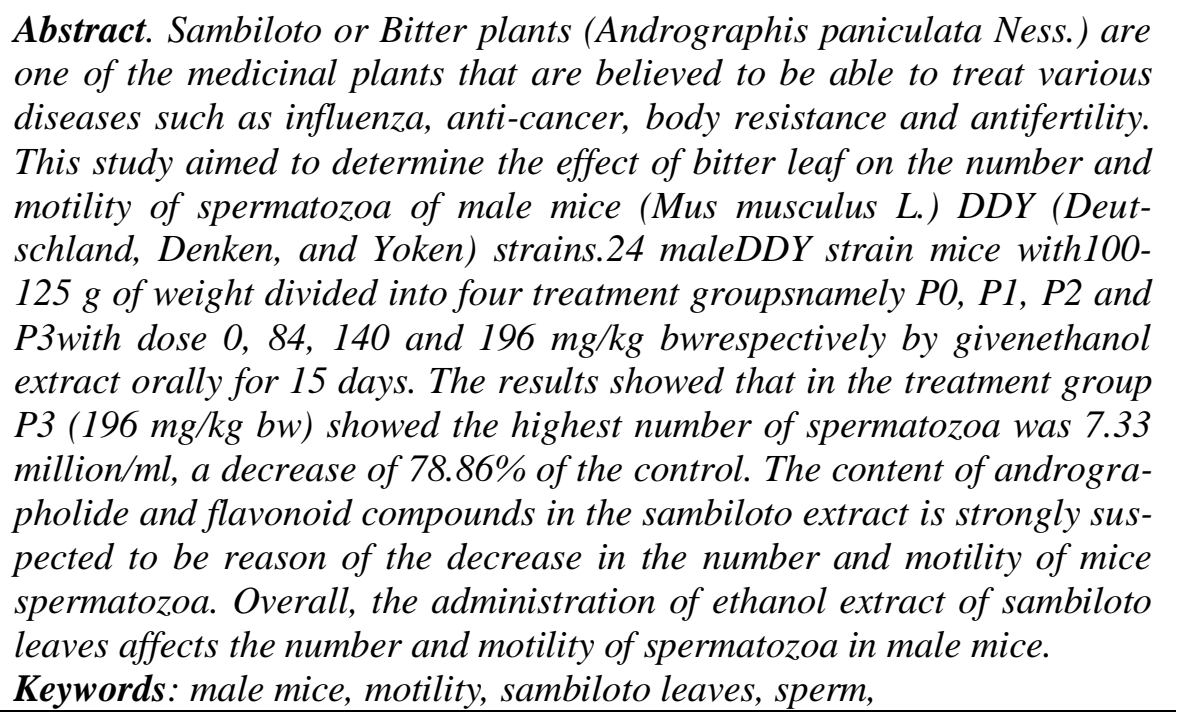




\section{JURNAL BIODJATI}

http://journal.uinsgd.ac.id/index.php/biodjati

\section{Cara Sitasi}

Susilo., Akbar, B. \& Pratinaningsih, I. (2018). Pengaruh Ekstrak Etanol Daun Sambiloto Terhadap Jumlah dan Motilitas Spermatozoa Mencit Jantan. Jurnal Biodjati, 3 (2), 166-172.

\section{PENDAHULUAN}

Pertambahan penduduk yang pesat merupakan salah satu masalah bagi negara-negara yang sedang berkembang termasuk Indonesia. Berdasarkan data Badan Pusat Statistik (2016), rata-rata pertumbuhan penduduk Indonesia masih diangka $1,49 \%$ per tahun. Hal tersebut berarti tiap tahun penduduk Indonesia bertambah sekitar 4 juta jiwa. Laju pertumbuhan penduduk yang tinggi tersebut dapat mengakibatkan ledakan jumlah populasi jika tidak diatasi dengan benar. Salah satu cara yang dilakukan pemerintah dari dulu adalah melalui program Keluarga Berencana.

Program Keluarga Berencana (KB) merupakan sarana penyediaan kontrasepsi yang bertujuan untuk pencegahan terjadinya peleburan antara sel sperma pria dengan sel telur wanita. Sarana kontrasepsi sebagian besar dilakukan oleh wanita dari peserta keluarga berencana, sedangkan partisipasi pria dalam ber-KB masih rendah, pilihannya masih berbatas pada penggunaan metode pencegahan kehamilan, seperti kontrasepsi kondom, vasektomi, metode senggama terputus, metode pantang berkala/ sistem kalender (Ekarini, 2008). Kelemahan alat kontrasepsi kondom memberikan ketidaknyamanan pada pasangan dan dapat menimbulkan alergi disekitar penis atau vagina. Sedangkan efek samping jangka panjang pada pria yang pernah menjalani program kontrasepsi seperti halnya vasektomi yaitu dapat terjadinya insidensi kanker testis dan kanker prostat (Anton \& Andari, 2013).

Salah satu usaha yang sedang dilakukan adalah menemukan obat antifertilitas bagi pria yang tidak memiliki efek samping (Daniyal \& Akram, 2015; Dzulfiqor, et al, 2015; Sunda- ram, 1990; Susilo \& Akbar, 2016). Penggunaan kontrasepsi alami untuk menghambat spermatogenesis agar sperma yang dihasilkan berkurang dapat dimanfaatkan para pasangan yang sudah berkeluarga dengan beralih ke tumbuhan sambiloto (Andrographis paniculata). Tumbuhan sambiloto telah diuji dan dipercaya memiliki kandungan kimia yang berpotennsi sebagai obat anti-fertilitas bagi pria (Allan et al, 2009; Lingampally, Solanki, \& Raja, 2012; Shah, Singh, Shah, \& Kakar, 2016; Sundaram, 1990). Kandungan kimia tersebut adalah andrografolid, yaitu senyawa kimia yang banyak terdapat di dalam sambiloto (Ashafa et al, 2012; Halim et al, 2004). Andrografolid merupakan zat aktif yang berfungsi mencegah pembelahan sel (sitokinesis). Andrographolide dapat mempengaruhi pertumbuhan normal dan perkembangan indung telur (ovarium) (Shinde et al, 2012). Mekanisme yang terjadi adalah proses gametogenesis pada tahap proliferasi mengalami penurunan yang mengakibatkan produksi spermatogonia juga akan menurun. Andrografolid dapat mempengaruhi jumlah produksi sel-sel sperma dalam tubuli seminiferi dan dapat berimbas pada jumlah spermatozoa yang dihasilkan (Adelati, Juniarto \& Miranti, 2016; Susanti et al, 2017). Penelitian yang dilakukan di India dengan hewan uji tikus jantan, tumbuhan sambiloto dalam bentuk serbuk daun kering dengan dosis $105 \mathrm{mg} / \mathrm{kg}$ berat badan yang diberikan selama 60 hari dapat menghentikan spermatogenesis pada tahap perkembangan dan pematangan sel- sel sperma (Dewi, 2013).

Mengingat animo masyarakat Indonesia belakangan ini lebih banyak memilih obat tradisional karena dianggap relatif lebih murah, efisien dan lebih aman dari efek samping diban 


\section{Jurnal Biodjati, 3 (2) 2018

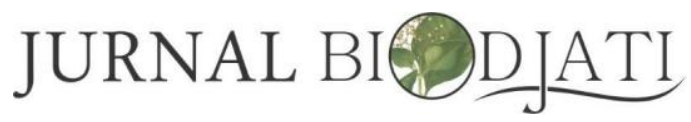

http://journal.uinsgd.ac.id/index.php/biodjati

dingkan dengan obat sintetik, maka penelitian pengaruh ekstrak etanol daun sambiloto terhadap jumlah dan motilitas spermaozoa mencit jantan penting untuk dilakukan, selain itu hasil dari penelitian ini dapat digunakan sebagai bahan rujukan bagi masyarakat dan para peneliti lain yang mengkaji topik yang relevan.

\section{BAHAN DAN METODE}

Penelitian dilaksanakan di Laboratorium Kesmavet Dinas Peternakan, Perikanan dan Kelautan Propinsi DKI Jakarta pada bulan April - Juni 2015. Rancangan penelitian menggunakan Rancangan Acak Lengkap (RAL) dengan empat kelompok perlakuan dan enam ulangan pada 24 ekor mencit jantan dengan berat antara 100-125gr. Dosis yang digunakan dalam penelitian yaitu P0 (kontrol), P1 (dosis $84 \mathrm{mg} / \mathrm{kg}$ berat badan), P2 (140 mg/kg berat badan) dan P3 (196 mg/kg berat badan) yang diberikan secara oral selama 15 hari perlakuan. Bahan yang digunakan adalah ekstrak etanol daun sambiloto yang diperoleh dari Balitro Bogor, aquabides, $\mathrm{NaCl}$ 0,9\%, klorofoam, etanol $96 \%$ dan alkohol $70 \%$. Alat yang digunakan adalah papan bedah, satu set alat bedah, hemositometer Improved Neubauer, cawan petri, mikroskop dan lain-lain.

Pada hari ke 16 mencit dibius dengan kloroform dan dibedah untuk pengambilan organ testis dan epididimis. Selanjutnya sample diletakkan di cawan petri yang berisi $1 \mathrm{ml}$ laru$\tan \mathrm{NaCl}$ 0,9\%. Perhitungan jumlah sperma dilakukan dengan pengenceran 20 kali pada pipet leukosit, dengan cara menghisap sperma menggunakan pipet leukosit sebanyak 0,005 ml. Selanjutnya, pipet yang berisi sperma dikocok membentuk angka delapan agar sperma homogen. Perhitungan jumlah sperma dilakukan dengan mengamati spermatozoa pada hemositometer Improved Neubauer di bawah Mikroskop Binokuler Olympus Cx22. Jumlah spermatozoa yang didapat dimasukkan ke dalam rumus perhitungan konsentrasi spermatozoa menurut Ilyas (2007) berikut ini.

$$
K S=\mathrm{n} \times 10.000 \times \mathrm{Fp} \times \frac{25}{k} \mathrm{x} \mathrm{vNaCl}
$$

Ket. KS: konsentrasi spermatozoa; n: jumlah sperma; Fp: Faktor pengenceran; k: jumlah kotak kecil Neubauer; vNaCl: Volume $\mathrm{NaCl}$ fisiologis; 10.000: Volume kamar hitung Neubauer; angka 25: jumlah kotak kecil Neubauer

Pengamatan motilitas spermatozoa dilakukan dengan mengamati intensitas pergerakan satu sel spermatozoa selama 1 menit dan dihitung berapa kali spermatozoa tersebut mengalami pergerakan ekor dengan cepat dan lurus ke depan. Data yang didapat kemudian diakumulasikan untuk selanjutnya dianalisis. Teknik analisis data dengan menggunakan program pengolahan data statistik yang meliputi uji normalitas, uji homogenitas, uji parametrik (one-way ANOVA) atau uji non parametrik (Kruskal Wallis). Bila pada data yang diperoleh terdapat perbedaan yang signifikan, maka dilanjutkan dengan uji Beda Nyata Terkecil (BNT).

\section{HASIL DAN PEMBAHASAN}

Penelitian ini difokuskan pada aktifitas anti-fertilitas bedasarkan pengaruh ekstrak etanol daun sambiloto terhadap jumlah dan motilitas sperma pada mencit jantan galur DDY. Berdasarkan hasil penelitian (Tabel 1), secara umum menggambarkan adanya penurunan jumlah dan motilitas spermatozoa dengan bertambahnya dosis ekstrak sambiloto yang diberikan pada hewan percobaan mencit jantan. Konsentrasi spermatozoa dalam semen harus cukup agar proses fertilisasi terjadi. Kategori konsentrasi spermatozoa normal yang 


\section{Jurnal Biodjati, 3 (2) 2018

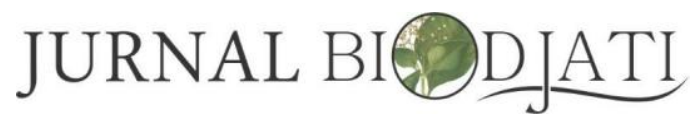

http://journal.uinsgd.ac.id/index.php/biodjati

didefinisikan oleh World Health Organization yaitu $>20 \times 10^{6} / \mathrm{ml}$ dan jika konsentrasi spermatozoa $<20 \times 10^{6} / \mathrm{ml}$ maka spermatozoa dalam kategori sub-fertile (Cooper et al, 2010).

Uji statistik menunjukkan perbedaan nyata antara empat perlakuan jumlah sperma dengan pemberian ekstrak etanol daun sambiloto (Gambar 1).

Penelitian dengan pemberian ekstrak etanol daun sambiloto terhadap mencit jantan pada kelompok kontrol menunjukan nilai ratarata jumlah spermatozoa sebesar 34,66 juta/ml (kategori normal). Hal tersebut dapat ditunjukan dari data kelompok kontrol yang jumlah spermatozoanya lebih dari $20 \mathrm{juta} / \mathrm{ml}$. Terjadi penurunan jumlah spermatozoa pada perlakuan P3 (dosis $196 \mathrm{mg} / \mathrm{kg}$ berat badan) dengan hasil rata-rata 7,33 juta/ml. Penurunan jumlah spermatozoa disebabkan adanya senyawa andrografolid dan flavonoid dalam sambiloto yang berfungsi sebagai antiandrogenik dengan cara menghambat enzim aromatase yaitu enzim yang berfungsi mengkatalis konfersi androgen menjadi estrogen yang akan meningkatkan hormon testosterone (Oyedemi, et al, 2010). Tingginya konsentrasi testosteron akan berumpan balik negatif ke hipofisis sehingga sedikit mensekresikan FSH dan LH yang akan berakibat mengganggu spermatogenesis. Seperti yang diketahui bahwa FSH bertugas dalam merangsang sel sertoli, fungsi sel sertoli yaitu bertanggung jawab terhadap pematangan sel spermatogenik dalam tubulus semineferus, seperti untuk suplai nutrisi, diferensiasi spermatid menjadi spermatozoa dan hormon untuk pematangan spermatozoa. Sel sertoli menjadi ciri spesifik untuk aktivitas metabolisme protein, seperti Androgen Binding Protein (ABP), protein tersebut disekresikan secara maksimal ketika tahap spermatogenesis, yaitu tahap spesifik pematangan sel selama perubahan spermatid berekor dan saat metamorfosis spermatid menjadi spermatozoa (Hansson, et al,
1978). ABP dari bagian basal akan mengikat testosteron yang berada pada membran tubulus seminiferus dan membawanya ke daerah lumen untuk dipergunakan menstimulasi tahap metamorfosis. Bila terdapat hambatan pada sekresi ABP oleh sel sertoli dapat dipastikan bahwa transport testosteron juga akan terganggu. Hal ini tentu juga akan berimbas pada stimulasi perubahan spermatid menjadi spermatozoa sehingga jumlah spermatozoa yang dilepas dalam lumen akan berkurang dan dihasilkan spermatozoa yang belum matang (Ma et al, 2015).

Kategori motilitas spermatozoa normal yaitu $>50 \%$ dan bila spermatozoa $<50 \%$ maka motilitas sperma dalam kategori subfertile (Johnson \& Everitt's, 2007). Hasil penelitian terhadap rata-rata motilitas spermatozoa dengan pemberian ekstrak sambiloto pada kelompok kontrol sebesar 110,83 kali/menit. Data tersebut tergolong kategori normal karena jumlahnya $>50 \%$ dan data tersebut mengalami penurunan pada kelompok P3 sebesar 75,16 $\mathrm{kali} / \mathrm{menit}$ dengan pemberian dosis $196 \mathrm{mg} / \mathrm{kg}$ berat badan ekstrak sambiloto. Data selengkapnya disajikan pada Gambar 2 berikut ini.

Hasil analisis statistik menunjukkan bahwa pemberian ekstrak etanol daun sambiloto dengan $\mathrm{P} 1$ dosis $84 \mathrm{mg} / \mathrm{kg}$ berat badan, $\mathrm{P} 2$ dosis $140 \mathrm{mg} / \mathrm{kg}$ berat badan dan P3 dosis 196 $\mathrm{mg} / \mathrm{kg}$ berat badan tidak berpengaruh nyata/ tidak signifikan perbedaannya dalam penurunan motilitas spermatozoa. Salah satu faktor penyebabnya adalah kurangnya prosedur pengamatan karena peneliti hanya mengamati intensitas pergerakan satu sel sperma selama satu menit untuk mengetahui sperma tersebut motil atau tidak. Pengamatan satu sel sperma ternyata belum dapat mewakili seluruh pergerakan sperma yang lainnya. Motilitas spermatozoa dipengaruhi lama waktu di epididimis, morfologi, flagel, antibodi, $\mathrm{pH}$, konaentrasi cairan atau sekret dan abnormalitas spermato 


\section{Jurnal Biodjati, 3 (2) 2018

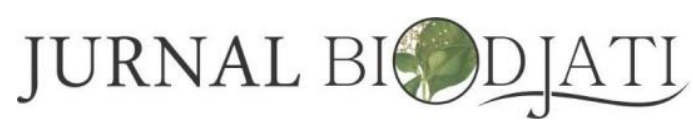

http://journal.uinsgd.ac.id/index.php/biodjati

zoa mengganggu produksi energi untuk bergerak (Erris \& Harahap, 2014).

Tanaman sambiloto mengandung senyawa andrografolid (senyawa keton diterpenoid, triterpenoid) dan senyawa flavonoid yangdiduga dapat menyebabkan abnormalitas organel sel pada bagian leher spermatozoa, sehingga menyebabkan fungsi mitokondria dalam menghasilkan energi tidak maksimal dan akhirnya berpengaruh terhadap penurunan motilitas spermatozoa. Bila sebagian spermatozoa yang dihasilkan mengalami abnormalitas dalam pembentukannya, maka hal tersebut akan berpengaruh pada saat pematangan di epididimis (Hansson et al, 1978). Pematangan sperma di epididimis terjadi selama 18 jam sampai 10 hari. Selama proses tersebut, sperma mengembangkan kemampuan bergeraknya walaupun beberapa faktor lain masih dapat mencegah motilitas spermatozoa sampai setelah ejakulasi terjadi (Arthur, 1990)

Berdasarkan hasil penelitian yang telah dilakukan maka dapat diketahui bahwa senyawa aktif andrografolid pada ekstrak sambiloto dapat mempengaruhi sel spermatogenik dalam testis khususnya spermatid dan spermatozoa. Sehingga pelepasan spermatozoa dari testis berkurang dan mengganggu pematangan di epididimis yang mengakibatkan gangguan nurunan jumlah dan motilitas spermatozoa.

Tabel 1. Hasil rata - rata jumlah sperma dan motilitas sperma

\begin{tabular}{ccc}
\hline Perlakuan & JS $(\mathrm{juta} / \mathrm{ml})$ & MS (kali/menit) \\
\hline P0 & $34,66^{\mathrm{a}}$ & $110,83^{\mathrm{a}}$ \\
P1 & $26,33^{\mathrm{b}}$ & $91,83^{\mathrm{b}}$ \\
P2 & $14,33^{\mathrm{c}}$ & $83,16^{\mathrm{b}}$ \\
P3 & $7,33^{\mathrm{d}}$ & $75,16^{\mathrm{b}}$ \\
\hline
\end{tabular}

Ket: JS= rerata jumlah sperma; $\mathrm{MS}=$ rerata motilitas sperma; Keterangan P0 (kontrol), P1 (dosis $84 \mathrm{mg} / \mathrm{kg}$ berat badan), P2 (140 mg/kg berat badan) dan P3 (196 mg/kg berat badan).

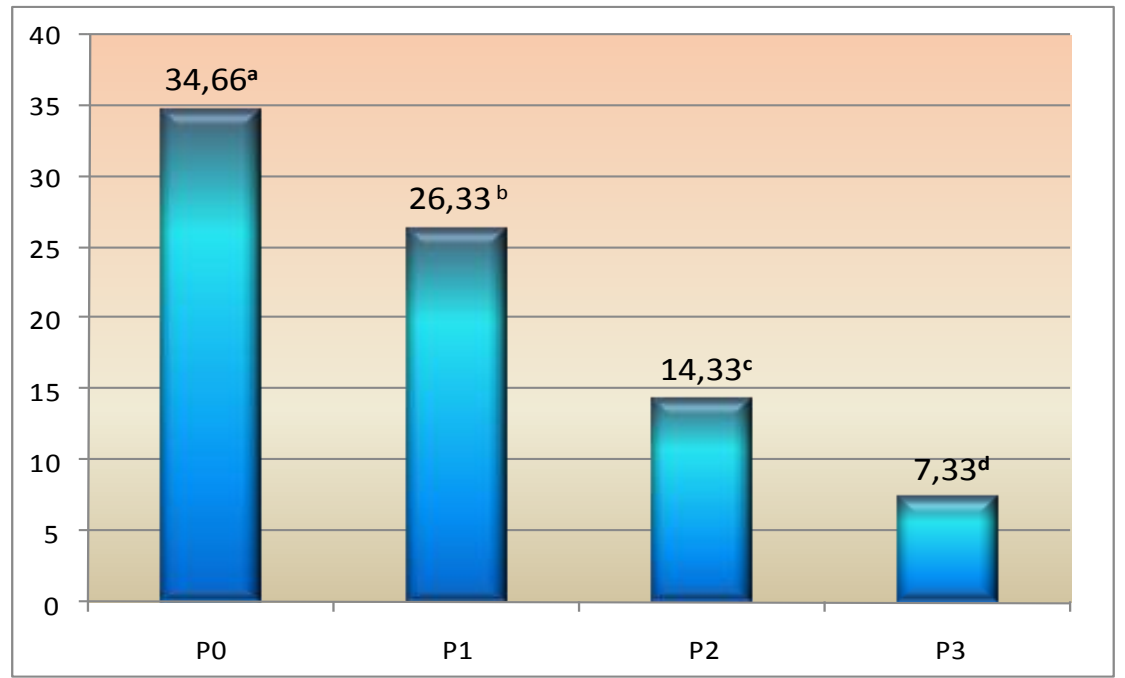

Gambar 1. Data jumlah sperma dengan pemberian ekstrak etanol daun loto. Keterangan P0 (kontrol), P1 (dosis $84 \mathrm{mg} / \mathrm{kg}$ berat badan), P2 (140 mg/kg berat badan) dan P3 (196 mg/kg berat badan). 


\section{JURNAL BIODJATI}

http://journal.uinsgd.ac.id/index.php/biodjati

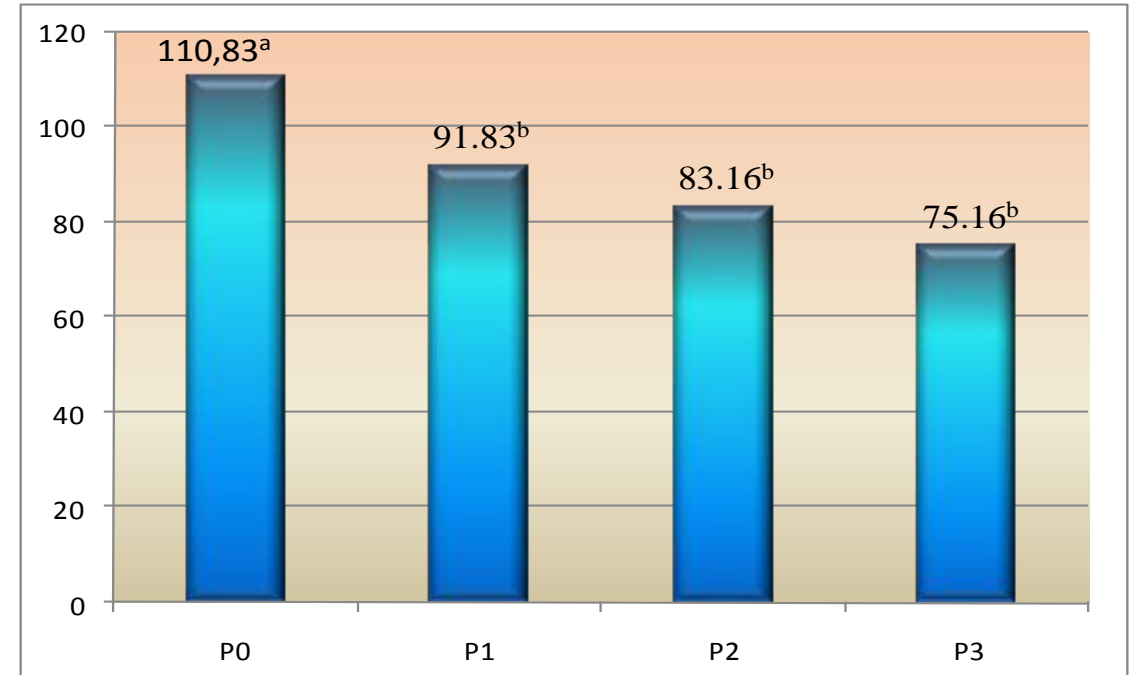

Gambar 2. Data motilitas sperma dengan pemberian ekstrak etanol daun sambiloto. Keterangan P0 (kontrol), P1 (dosis $84 \mathrm{mg} / \mathrm{kg}$ berat badan), P2 (140 $\mathrm{mg} / \mathrm{kg}$ berat badan) dan P3 (196 mg/kg berat badan).

\section{KESIMPULAN}

Pemberian ekstrak sambiloto (Andrographis paniculata) berpengaruh terhadap jumlah spermatozoa. Pemberian ekstrak etanol daun sambiloto dengan dosis terbaik yaitu 196 $\mathrm{mg} / \mathrm{kg}$ berat badan pada perlakuan tiga berpengaruh nyata terhadap penurunan jumlah spermatozoa sebesar 78,86\% terhadap kontrol. Pemberian ekstrak etanol daun sambiloto pada kelompok perlakuan tidak berpengaruh nyata terhadap penurunan motilitas spermatozoa.

\section{DAFTAR PUSTAKA}

Adelati, S., Juniarto, A. Z. \& Miranti, I. P. (2016). Histopatologi Spermatogenesis Testis Tikus Wistar Diabetes melitus. Jurnal Kedokteran Diponegoro, 5(4), 17601769.

Allan, J. J., Pore., M. P., Deepak, M., Murali, B., Mayachari., A. S. \& Agarwal, A. (2009). Reproductive and Fertility Effects of an Extract of Andrographis Paniculata in Male Wistar Rats. International Jour- nal of Toxicology, 28(4), 308-317.

Anton, D. \& Andari, D. (2013). Memilih Kontrasepsi Alami dan Halal. Solo: Aqwamedika.

Arthur, C. G. (1990). Fisiologi Manusia dan Mekanisme Penyakit. Jakarta: Buku Kedokteran EGC.

Ashafa, A. O. T., Orekoya, L. O. \& Yakubu, M. T. (2012). Toxicity Profile of Ethanolic Extract of Azadirachta Indica Stem Bark in Male Wistar Rats. Asian Pacific Journal of Tropical Biomedicine, 2(10), 811-817.

Badan Pusat Statistik. (2016). Statistik Indonesia 2016. (S. P. dan K. Statistik, Ed.) (Vol. 3). Jakarta: Badan Pusat Statistik.

Cooper, T. G., Noonan, E., Eckardstein, S. von, Auger, J., Baker, G., Behre, H. M. \& Mbizvo, M. T. (2010). World Health Organization Reference Values for Human Semen Characteristics. Human Reproduction Update, 16(3), 231-245.

Daniyal, M. \& Akram, M. (2015). Antifertility activity of medicinal plants. Journal of the Chinese Medical Association, 78(7), 382- 


\section{JURNAL BIODJATI}

http://journal.uinsgd.ac.id/index.php/biodjati

388.

Dewi, N. (2013). Khasiat \& Cara Olah Sambiloto untuk Menumpas Berbagai Penyakit. Yogyakarta: Pustaka Baru Press.

Dzulfiqor, Y., Akbar, B. \& Susilo, S. (2015). Uji Ekstrak Etanol Daun Pegagan (Centella asiatica L. Urban) Terhadap Fertilitas Tikus Putih (Rattus norvegicus L.) Betina pada Tahap Praimplantasi. Al-Kauniyah, 8(2), 101-107.

Ekarini, B. (2008). Analisis Faktor-Faktor yang Berpengaruh Terhadap Partisipasi Pria dalam Keluarga Berencana di Kecamatan Selo Kabupaten Boyolali. Universitas Diponegoro.

Erris \& Harahap, I. (2014). Pengaruh Kebisingan Terhadap Kuantitasdan Kualitas Spermatozoa Tikus Putih (Rattus norvegicus) Jantan Dewasa. Media Litbangkes, 24(3), 123-128.

Halim, V. S., Soegihardjo, C. J. \& Rizal, D. M. (2004). Pengaruh Ekstrak Etanol Herba Sambiloto (Andrographis paniculata (Burm.f.) Nees) Terhadap Spermatogenesis Mencit Jantan Dewasa dan Uji Kualitatif Kromatografi Lapis Tipis. Majalah Farmasi Indonesia, 15(3), 136-143.

Hansson, V., Djøseland, O., Reuseh, B., Attramadal, A. \& Torgersen, O. (1978). An Androgen Binding Protein in The Testis Cytosol Fraction of Adult Rats. Comparison with the androgen binding protein in the epididymis. Steroids, 21(3), 457-474.

Ilyas, S. (2007). Azoospermia dan Pemulihannya Melalui Regulasi Apoptosis Sel Spermatogenik Tikus (Rattus sp) pada Penyuntikan Kombinasi $T U \& M P A$. Universitas Indonesia.

Lingampally, V., Solanki, V. R. \& Raja, S. S. (2012). Andrographolide: an effective anti-fertility Agent for The Control of Tribolium Confusum. Asian Journal of Plant Science and Research, 2(3), 313-317.
Ma, Y., Yang, H. Z., Xu, L. M., Huang, Y. R., Dai, H. L. \& Kang, X. N. (2015). Testosterone Regulates the Autophagic Clearance of Androgen Binding Protein in Rat Sertoli Cells. Scientific Reports, 5, 1-8.

Oyedemi, S., Yakubu, M. \& Afolayan, A. (2010). Effect of Aqueous Extract of Leonotis leonorus (L.) R. Br. Leaves in Male Wistar rats. Hum. Exp. Toxicol, 29, 377384.

Shah, M., Singh, R., Shah, R. \& Kakar, S. (2016). An Overview of The Current Methodologies Used for Evaluation of AntiFertility Agents. Asian Pacific Journal of Reproduction, 5(3), 175-178.

Shinde, N., Chauhan, A. S., Sanjay, K., Gupta, Bodakhe, S. H. \& Pandey, D. P. (2015). Antifertility Studies of Curcumin and Andrographolide Combination in Female Rats. Asian Pacific Journal of Reproduction, 4(3), 188-194.

Sundaram, J. (1990). Antifertility effects of andrographolide in rats. J. Ecobiol, 2 (4).

Susanti, N. M. P., Warditiani, N. K., Juwianti, C., \& Wisesa, I. N. T. (2017). Potensi Toksisitas Andrografolid dari Sambiloto (Andrographis paniculata (Burm.f.) Nees) Pada Kulit dan Mata Secara In Silico. Jurnal Farmasi Udayana, 6(1), 47-49.

Susilo, \& Akbar, B. (2016). Pengaruh Ekstrak buah takokak (Solanum torvum S.) Terhadap Jumlah dan Motilitas Spermatozoa Tikus Putih (Rattus norvegicus L.) galur Sprague Dawley. BIOMEDIKA, 9(2), 4551. 